\title{
Smallpox: \\ Local Epidemics and the Iowa State Board of Health, 1880-1900
}

\author{
PHILIP L. FRANA
}

Our School Board has refused to issue an order compelling all children attending the public schools to be vaccinated . . . claiming that there is no law for the same, and that they can resort to no compulsory measures in this respect. Holding a different opinion, that the order should be issued as a sanitary and precautionary measure, I desire to obtain the decision of State Board. ... If I am wrong, what action should be taken?

—Dr. Charles H. Lathrop, Lyons, Iowa

Have we the authority as a local board of health to enforce vaccination? We have passed an ordinance to that effect, as we have variola near us.

—Dr. M. Y. Baker, Fayette, Iowa

Small-pox eight miles east of here. People passing. What shall I do? Answer.

- Dr. M. T. Martin, Woodburn, Iowa ${ }^{1}$

IOWA'S INAUGURATION of a State Board of Health in 1880 introduced Iowa communities, railroads, and health care providers to a new source of potential support in the battle against smallpox. By promising to rid towns of scourges of diseases that had agitated citizens since territorial days, board physicians

1. State Board of Health, Biennial Report 2 (1883), 12, 17; Ibid. 4 (1887), 49.

THE ANNALS OF IOWA 54 (Spring 1995). OThe State Historical Society of Iowa, 1995. 
pledged to win a war against a whole host of "specific febrile diseases," including scarlet fever, diphtheria, and smallpox.

Unlike the midwestern metropolises-Chicago, Milwaukee, and St. Louis - most Iowa towns lacked highly organized health boards throughout the nineteenth century. Responding to each epidemic of disease, Iowa towns formed boards ad hoc and organized relief efforts both to stem the tide of disease and to protect the local economy. Physicians of the State Board of Health quickly learned to use efforts to control smallpox as a way to introduce autonomous municipal and business interests to the potential benefits of centralized public health. ${ }^{2}$

Armed with knowledge gained from nearly a century of experiments in fighting the disease, the board made vaccination, quarantine, and reporting of the disease centerpieces of its activities. With the sanction of a National Board of Health, the Iowa State Board also advanced regulations directed at interstate passenger railroad cars and the diseases thought to be harbored within. For the remainder of the century, smallpox prevention and control was seen by both physicians and lay people as the most powerful weapon in the board's arsenal. Although of dubious effect, the efforts made by the Iowa State Board of Health to rid rural communities of smallpox served, to some extent, to supplement the actions of local authorities, who sought to protect their communities not only from smallpox, but from immigrants and economic ruin as well.

SINCE COLONIAL TIMES local health boards had been formed to ameliorate the ill effects of American urban life. Visitors and residents alike often noted the apparent sickliness

2. Robert H. Wiebe has suggested in The Search for Order, 1877-1920 (New York, 1967), xiii, that the United States as a whole acted as a system of isolated "island communities" for much of the nineteenth century, largely because of poor communication links between cities. A fascinating narrative of the role of the State Board of Health as a flash point for medical reform in Iowa is in Lee Anderson, "'Headlights upon Sanitary Medicine': Public Health and Medical Reform in Late Nineteenth-Century Iowa," Journal of the History of Medicine and Allied Sciences 46 (1991), 178-200. For a discussion of the movement from local to regional and national control over matters of public health, consult Alan I Marcus, "Disease Prevention in America: From a Local to a National Outlook, 1880-1910," Bulletin of the History of Medicine 53 (1979), 184-203. 
of exploding seaboard populations. Immigrants, besides bringing strange languages and habits, also brought exotic diseases that threatened to lay waste to America's capitalist experiment. Throughout the nineteenth century, sanitation, which in the mid-nineteenth century meant controlling the environmental factors that caused disease, was a chief worry of these local boards. Most diseases were believed to arise spontaneously from rotting garbage and other effluvia - that is, unless you were a contagionist, in which case you blamed "morbific poisons" or explained disease in terms of chemical reactions. ${ }^{3}$

Smallpox, though, was regarded by most as a special case. Although it was generally considered an atmospheric pollutant or organic poison like other diseases, quantifiable evidence was accumulating indicating that smallpox could be prevented. Before Edward Jenner developed his vaccination in 1796, a case of smallpox inevitably ended with either death or lifetime immunity. A confluent case, with oozing pustules carpeting the body, was one of the most hideous afflictions of human history. Vaccination and the proliferation after 1890 of a more benign strain of the virus called Variola minor with very low mortality (less than 1 percent) and immunity-conferring properties had changed the nature of the threat from the disease. Like a tiger caught in a trap, perennial waves of the disease, regarded as rights of passage for infants and the young, were stopped in their tracks as millions worldwide benefited from the limited protection of the cowpox vaccine. ${ }^{4}$

By the last quarter of the century, however, the tiger had escaped. Epidemics, often of the milder $V$. minor strain, were showing up again in the immigrant quarters of eastern cities, and subsequently reappeared in the Midwest. A new generation was not being immunized as quickly as the last. Some people, harboring an artificial sense of security, flatly refused to accept vaccination. Others felt that the danger posed by vaccination

3. Martin V. Melosi, Garbage in the Cities: Refuse, Reform, and the Environment, 1880-1980 (College Station, TX, 1981), 3-15; Charles V. Chapin, "History of State and Municipal Control of Disease," in A Half Century of Public Health, ed. Mazyck P. Ravenel (New York, 1921), 136-38.

4. Alfred W. Crosby, "Smallpox," in The Cambridge World History of Human Disease, ed. Kenneth F. Kiple (Cambridge, 1993), 1008-9, 1012. 
outweighed the threat from the disease itself. A banker from Nora Springs, Iowa, led the opposition with an ill-conceived nationwide antivaccination organization. ${ }^{5}$

Despite opposition and indifference toward attempts to organize a systematic response to epidemics, municipal health boards inched their way into the American experience after the Civil War, alternately appearing and disappearing as crises came and went. Chicago created its first local board in 1867 in response to a pandemic of cholera, but when the crisis passed, the organization nearly collapsed. Chicago's experience was mirrored in many urban areas both large and small. During epidemics, cities created ad hoc boards composed of a mixture of physicians, elected officials, school board members, ministers, and other community leaders. They issued and enforced municipal edicts, whether promulgated in code or not. Only a handful of midwestern cities, including the Iowa towns of Keokuk and Dubuque, had boards of health that were articulated duties of county trustees, mayors, and physicians. Even there, though, board activities were often neglected except in times of emergency. In general, these local boards' effectiveness in rallying citizens was uneven at best. Often their success depended on the sensational power of the press, which unfortunately also had an irritating tendency to magnify anxiety despite claims to the contrary. ${ }^{6}$

In response to the need for more expansive control over teeming immigrant cities, state boards of health had been proposed for several of the more populous eastern states beginning in the mid-nineteenth century. Lemuel Shattuck's Report of the Sanitary Commission of Massachusetts (1850) became the manifesto for late nineteenth-century American health reform, although nearly two decades would pass before the first state boards were created following his recommendations. During that time, Shattuck lectured widely in the East about the pressing need

5. Phyllis Allen Richmond, "American Attitudes toward the Germ Theory of Disease (1860-1880)," Journal of the History of Medicine 9 (1954), 428-31. See also Martin Kaufman, "The American Anti-Vaccinationists and Their Arguments," Bulletin of the History of Medicine 41 (1967), 463-78.

6. Chapin, "History of State and Municipal Control of Disease," 136-38. 
to coordinate public health activities on a grander scale in order to meet sanitary and pestilential challenges. Shattuck's central contention was that mean life expectancy in the United States had actually decreased while that of health-reforming Europe was increasing by leaps and bounds during the century. To improve American health he advised states to devise uniform classification of causes of death, provide health education, and vaccinate the populace. Although Shattuck's work was ignored by his contemporaries, his ideas were pointedly recast in legislation establishing state boards in Massachusetts (1869) and, ironically, in the western states of California (1870), Minnesota (1872), Wisconsin (1876), Illinois (1877), and Iowa (1880). ${ }^{7}$

IN THE LATE 1870s members of the Iowa State Medical Society, drawing on their growing sense of professionalism and "pride as public spirited citizens of a growing commonwealth," began lobbying the state legislature for the creation of a State Board of Health. On March 26, 1880, the legislature gave final approval for an Act to Establish a State Board of Health. The board was to be composed of nine individuals - the Iowa attorney general, a civil engineer, and seven physicians - all appointed by the governor. The physicians were appointed to staggered terms of seven years, one physician being replaced each year. The legislature allotted five thousand dollars to run the board, including a comfortable twelve hundred dollars for the secretary. Modeled after the Illinois state board, the Iowa board was charged with the responsibility of supervising matters related to the health and welfare of Iowa's residents. Specifically, the board's activities were to include acting as the "medical police"

7. Lemuel Shattuck, Report of the Sanitary Commission of Massachusetts, 1850 (1850; reprint, Cambridge, MA, 1948), v-ix; Chapin, "History of State and Municipal Control of Disease," 138-39; Barbara Gutmann Rosenkrantz, Public Health and the State: Changing Views in Massachusetts, 1842-1936 (Cambridge, MA, 1972), 22. For the institution of other community and state boards of health, see Judith Walzer Leavitt, The Healthiest City: Milwaukee and the Politics of Health Reform (Princeton, NJ, 1982); John Duffy, A History of Public Health in New York City, 1866-1966, 2 vols. (New York, 1974); Isaac D. Rawlings, The Rise and Fall of Disease in Illinois (Springfield, IL, 1927); and James H. Cassedy, Charles V. Chapin and the Public Health Movement (Cambridge, MA, 1962). 
for physicians, providing a forum for advances in public health, mobilizing local organizations to control epidemic outbreaks, and collecting statistics on disease. ${ }^{8}$

The law assigned various responsibilities to the board, but lacked meaningful provisions for enforcement. For example, the legislature included sections in the state code requiring that physicians and midwives register with the county clerk of court to ensure accurate and complete health reporting to the board. A ten-dollar penalty was to be assessed for failure to report deaths to the clerk of court within thirty days of their occurrence. But enforcement was an unpaid extension of court clerks' duties, so the system remained weak. As a result, death records for the late nineteenth century are frustratingly inaccurate and unsystematic. In fact, poor recording by court clerks and delays in gathering the data prompted the state board to encourage health and medical authorities to report significant outbreaks of disease directly to the board's offices in Des Moines by telegraph. In practice, the board's activities were limited largely to suggesting quarantines where appropriate; collecting some statistical information on births, deaths, and marriages; and investigating hazardous sanitary conditions. ${ }^{9}$

The importance of smallpox prevention in the Iowa State Board of Health's plan of attack is indicated by the disproportionate number of pages in the board's biennial reports given over to discussion of the nature and spread of smallpox. The mortality rate from smallpox was relatively insignificant com-

8. D. S. Fairchild, "A Brief History of the Iowa State Board of Health," Journal of the Iowa State Medical Society 4 (1914), 467; Laws of Iowa (1880), chap. 151; Annotated Code of Iowa (1897), sec. 4977-78, 4998. The board for a time included among its membership two homeopaths and an eclectic. By 1890, Iowa's eclectic and homeopathic practitioners were generally absorbed into the mainstream of Iowa medicine provided they severed their overt ties to sectarian organizations. See William G. Rothstein, "The Botanical Movement and Orthodox Medicine," in Other Healers: Unorthodox Medicine in America, ed. Norman Gevitz (Baltimore, 1988), 47-50; Martin Kaufman, "Homeopathy in America: The Rise and Fall and Persistence of a Medical Heresy," ibid., 99-101, 106; Anderson, "'Headlights upon Sanitary Medicine,'" 187.

9. Laws of Iowa (1880), chap. 151. Not until 1923 did Iowa gain admittance to the National Death Registration System formed in 1880 to improve and systematize the death certification process. 
pared to all other epidemic or "zymotic" diseases present in Iowa at the time, including diphtheria, scarlet fever, and tuberculosis. Between 1800 and 1900, nearly 20 percent of all deaths involved epidemic diseases. Tuberculosis accounted for about 10 percent of those deaths caused by epidemic diseases, diphtheria 3 percent, and smallpox less than 0.5 percent. Still, the board's reports were dominated by the discussion of issues related to smallpox. ${ }^{10}$

There is no "representative" or average smallpox epidemic in Iowa in the last two decades of the nineteenth century. The yearly tally of cases fluctuated widely. Furthermore, records are available only on a county by county basis, making it difficult to follow epidemics, which have no respect for political boundaries. Still, some general observations on the nature and extent of smallpox in Iowa are possible. First, smallpox was not endemic to the state; all cases of the disease reported in the state were imported. Second, epidemics in Iowa during these years burned themselves out within months as the susceptible human reservoir was quickly exhausted. By nature, smallpox requires a dense and vulnerable human population to sustain itself. Only a few midwestern cities - Chicago, Milwaukee, St. Louis, and perhaps Omaha - had the population density to sustain smallpox. Apparently, Iowa's rural character gave smallpox no foothold for permanent establishment. Thus, for some years between 1880 and 1900, few cases were reported to the board, while other years witnessed a flurry of cases (see table).

In sum, the number of cases and their risk appears singularly unremarkable, even in light of the underreporting of epi-

10. The very first Biennial Report, published in 1881, contained twelve references to smallpox and vaccination, compared with ten to scarlet fever, two to measles, one to dysentery, and one to cholera. Only diphtheria evoked similar treatment, with eleven references. The next volume listed 26 references to smallpox, 14 to scarlet fever, and 9 to diphtheria. Even at the end of the century, when tuberculosis began to menace the health of Iowans, the Biennial Report gave more than 56 pages to smallpox versus 33 to consumption. State Board of Health, Biennial Report 1 (1881), 333-46 (hereafter cited as Biennial Report); ibid. 2 (1883), 403-417; ibid. 5 (1889), 191. In all, the Biennial Reports published between 1881 and 1901 devoted 227 pages to smallpox and vaccination; 98 pages described quarantine procedures. I computed causes of death from a random sampling of entries in county death registers in Iowa. 
TABLE 1

NUMBER OF SMALLPOX CASES IN IOWA

REPORTED TO THE STATE BOARD OF HEALTH, 1881-1901

\begin{tabular}{lrlr}
\hline Year & Cases & Year & Cases \\
\hline 1881 & 85 & 1890 & n.a. \\
1882 & n.a. & $1891-93$ & 3 \\
1883 & 596 & $1894-95$ & 117 \\
1884 & 35 & $1896-97$ & 4 \\
1885 & 59 & 1898 & 249 \\
$1886-87$ & 74 & 1899 & 646 \\
$1888-89$ & 51 & $1900-1901$ & 4148 \\
\hline
\end{tabular}

SOURCE: Iowa State Board of Health, Biennial Reports, 1881-1901.

demic diseases. The rate of morbidity was low, ranging from about 2 to 100 cases per 100,000 yearly. Approximately 75 percent of all epidemics reported to the State Board of Health between 1880 and 1900 involved fewer than 20 individuals; 15 percent involved between 20 and 50 cases; and only 10 percent more than fifty. The three largest epidemics in Iowa during this period - all between 1899 and 1901 - resulted in a total of 1,042 cases. In each of the three "worst" epidemics, the affliction was described as more like chicken pox in its character than like the killer of previous centuries. Natural attenuation of the virus, rather than any specific medical or hygienic treatment, was likely responsible for the weakened effect of the virus. ${ }^{11}$

Nonetheless, Iowans perceived smallpox to be more prevalent and more dangerous than it actually was. Much of this misconception can be explained by the terrible sight of the victims and the lightning nature of its spread. Iowa press headlines trumpeting lurid tales of smallpox epidemics in faraway places, such as Great Britain and Asia, also had their effect. In addition, Iowans' dread of smallpox had as much to do with fears of economic and social dislocation caused by immigrants and their diseases as it did with the possible adverse health effects of the disease. These considerations, however, did not

11. Raw data from the Biennial Reports, 1881-1901. 
MAP

LOCATIONS OF SERIOUS OUTBREAKS

OF SMALLPOX IN IOWA, 1880-1901

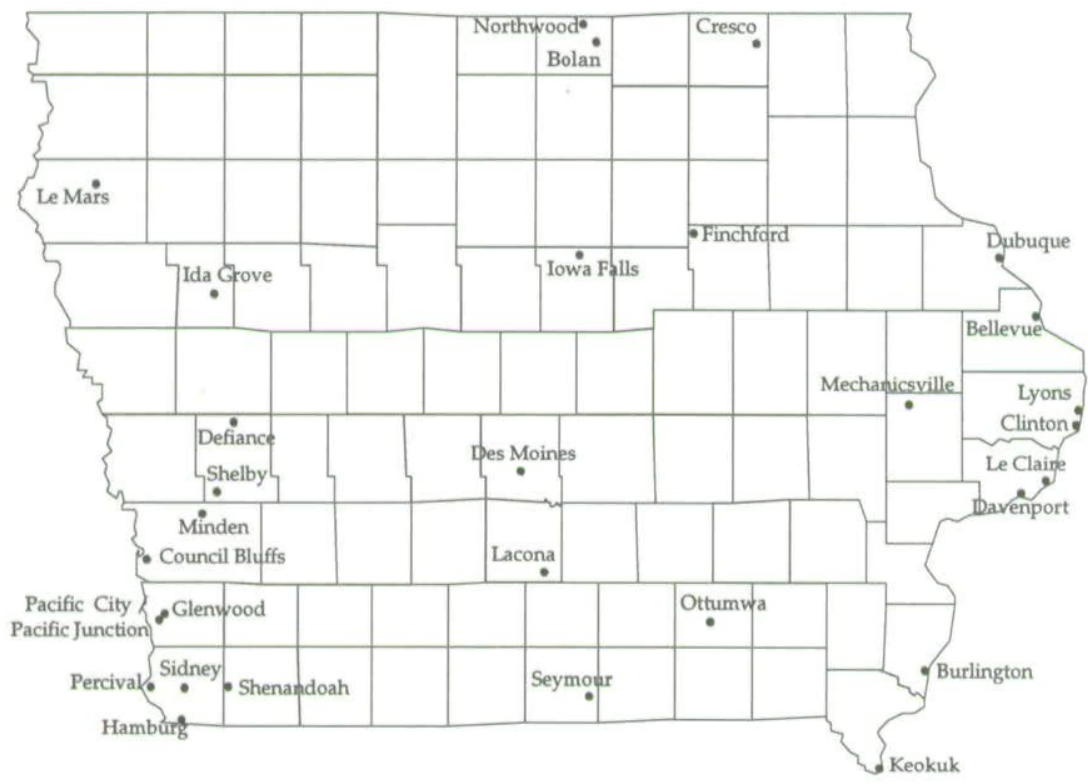

diminish the real threat epidemics of smallpox posed for those who lived in its shadow.

Tracing the course of local epidemics of smallpox in Keokuk, rural Worth County, and Fremont County illustrates the evolving relationship between the State Board of Health and local boards, both of whom had to take into account local economic interests. As city business faltered during Keokuk's bizarre 1882 smallpox epidemic, the new state board aid offered no aid. Several years later, Worth County boards accepted help from the state board to counteract the threat from immigrants and travelers. In 1898-99 Fremont County officials were more interested in blasting the failure of Nebraska City physicians to quarantine exposed individuals who brought the disease across the river, wreaking havoc on local trade. Nebraska City in turn blamed the economic powerhouse of Omaha for disrupting its own commerce. The Chicago \& North Western epidemic of 1889 reveals the threat posed by high-speed transportation systems 
and their passengers. In protecting their communities from disease, Iowans' xenophobic reaction to the immigrants and other strangers carried by the railroads reflects, to some extent, what historian Alan M. Kraut has recently termed the "double helix of health and fear." The state board certainly did not solve the economic, immigrant, or jurisdictional problems created by outbreaks of disease but became, rather, a new player troubled by the same things. ${ }^{12}$

THE FIRST SIGNIFICANT SMALLPOX EPIDEMIC in Iowa after the establishment of the State Board of Health occurred in Keokuk, ironically the site of Iowa's oldest and largest medical school and the hometown of the president of the Iowa State Medical Society. This 1882 epidemic, which made national headlines, began when a student nicked himself with a scalpel drawn from a smallpox-infected cadaver. In all, seventy-one cases were reported to the State Board of Health, with nine confirmed deaths. ${ }^{13}$

Keokuk in 1882 was better prepared than most cities to wage a war against smallpox and other pestilential diseases. Occupying a low-lying area at the confluence of the Mississippi and Des Moines Rivers, Keokuk had experience in previous decades with malaria, cholera, and yellow fever epidemics that spread along the Mississippi River. Keokuk had a well-worn pest house - a small wooden shack - on the outskirts of town where individuals with smallpox, malaria, and other afflictions were isolated. Medical facilities beyond the ramshackle pest house were far in advance of others in the state, with the possible exception of the recently established medical department

12. Alan M. Kraut, Silent Travelers: Germs, Genes, and the "Immigrant Menace" (New York, 1994), 9.

13. Hannibal Courier, reprinted in the Keokuk Constitution, 12 January 1882; Keokuk Weekly Gate City, 2 February 1882; New York Times, 6 January 1882. Local newspaper clippings related to the smallpox epidemic are conveniently collected in the R. J. Bickel Notebook Collection, a topical collection of newspaper clippings on the history of Keokuk. The original notebook is held at the Lee County, Iowa Historical Society, Keokuk. A microfilm copy is held at the State Historical Society of Iowa, Des Moines. The portion dealing with the smallpox epidemic is on reel 4, pp. 55-65. This epidemic, perhaps because of its novelty, is the most fully documented of the four described here. 
at the State University in Iowa City. The Keokuk College of Physicians and Surgeons, a 250-bed facility expanded during the Civil War with financial support from the federal government, was one of the largest hospitals west of the Mississippi. Hundreds of medical students boarded locally in private residences when classes were in session. And only two years before the epidemic the college had graduated its largest class in history, 221 expectant practitioners. Thus the town had a ready supply of physicians and students willing to practice their arts on the local inhabitants. ${ }^{14}$

Keokuk's experience with infectious crew and passengers on riverboats and its well-established medical community provided little guidance, however, when smallpox broke out in town on Christmas Day, 1881. By January 6, the local newspaper, the Keokuk Constitution, began reporting about what it considered "the absurdity of the small-pox craze in Keokuk." Recalling that this was not Keokuk's worst epidemic nor presumably to be its most deadly, the Constitution reminded citizens,

During the war there were a hundred or two cases of small-pox in Keokuk much of the time; yet there was no stoppage of business nor a general craze on the part of the citizens. . . Formerly scores of cases were treated in the pest house situated on the bluffs within a hundred yards of town. Yet there was no such alarm as the one which has prevailed in this city for the past ten days. To-day there is more small-pox in central Iowa than in the river towns, and more by long odds in some of our neighboring cities than in Keokuk. . . . Keokuk has done noisily and to her needless detriment what other cities have accomplished quietly, effectually and without material loss. ${ }^{15}$

Keokuk had no effective local health board in place to deal with this epidemic, although the municipal code charged the mayor and council with the responsibility. This was not unusual. Keokuk had no board during the devastating cholera epidemic of 1876 , or during the recurrent smallpox epidemics of 1862-1864.

14. William J. Petersen, The Story of Iowa: The Progress of an American State, 2 vols. (New York, 1952), 775-76; Transactions of the Iowa State Medical Society 6 (1883-85), 489-98.

15. Keokuk Constitution, 6 January 1882. 
Hastily, then, a local board of health was formed of city officials, trustees, and physicians to issue proclamations quarantining all those suspected of exposure to the disease. At the same time, two local newspapers, the Keokuk Constitution and the Weekly Gate-City were enlisted to salvage the city's image and economy. ${ }^{16}$

Efforts of the Keokuk board came too late for the afflicted, although its promotion of vaccination certainly protected many. The board's first action-closing the medical college where the disease originated-backfired. Since none of the students and faculty at the institution lived in on-site dormitories, the gesture was meaningless as a quarantine strategy. In fact, school closure provided the excuse for "a stampede of the students" to their homes in the tri-state area. Towns across the region bashed the Keokuk board in the press for its inability to control the epidemic. The city council of the town of Warsaw, only five miles from Keokuk warned its residents to "abstain from all communication with said city of Keokuk," and recommended that local hotels turn away all "strangers or visitors" for the duration. ${ }^{17}$

The board's vaccination efforts began with local schools, and by January 16 the Keokuk Constitution reported that "the little pretty white arms [of students] were scratched and mutilated in wholesale numbers." The board also assigned a physician to go house to house in each of four districts in the city seeking voluntary vaccinations. They encountered unexpected public resistance. "I s'pose you've come to vaccinate us," one woman was quoted as saying, "And ye might jest as well go away agin, for we won't have it." At one house a "colored brother" refused vaccination because, according to him, a relative who had been vaccinated in Georgia died one month later from the measles, so none of his family was ever going to be vaccinated. At another house a young girl declined vaccination for her brothers and sisters, saying, "The folks was all away from home, sir, besides, they was all vaccinated last year, and we had the small-pox when we lived in Missouri!" Others

16. Lee Anderson, Iowa Pharmacy, 1880-1905: An Experiment in Professionalism (Iowa City, 1989), 15; Keokuk Weekly Gate-City, 5 January 1882; Keokuk Constitution, 12 January 1882.

17. Keokuk Constitution, 6 January 1882. 
argued that American rights to freedom and independence implied the right to refuse vaccination. ${ }^{18}$

In response to such resistance, the board, in an open letter, demanded that the public give vaccinators "courteous treatment" and allow them to "enter into the work of vaccination at once" as they were "using none other than bovine (animal) virus of the purest quality." Although no penalties were drawn up for noncompliance, the majority of Keokuk's population had been vaccinated or revaccinated by the end of February. "The common remark now is, 'don't touch my sore arm,'" reported the Constitution. ${ }^{19}$

Efforts by the local board to promote vaccination and quarantine were further hampered when the medical college's officials insisted on reopening the school immediately and local businessmen sought to minimize the impact on trade. The pestering by officials of the medical college to restart classes as soon as possible created a minor sensation, undermining efforts by the local board to maintain control over the populace. "The faculty of the medical college appears to be determined to open that institution next Monday," complained the editor of the Constitution, while the board of health is equally determined that it shall not be. We trust the matter will be settled quietly, as it should be." The competing factions eventually reached a compromise, and following a thorough disinfection of the dissecting laboratory, the school reopened. On the first day of resumed classes, the Constitution marked the occasion by describing the unapologetic pledge of the "medica, with sails spread for a voyage across the Esculapian sea, [to] take proper precautions to avoid infected cadavers." ${ }^{20}$

Shortly after the epidemic broke out, a Constitution headline cogently summarized the worries of the business community: "The Danger Line Already Passed-No Apprehension Felt on the Part of the Physicians-Effect on Trade." In the wake of the epidemic, Keokuk citizens wanted to snatch their economic chestnuts from the fire. As long as there were reminders that
18. Ibid., 21 January 1882.
19. Ibid., 16 January 1882.
20. Ibid., 5, 14, 16 January 1882. 
smallpox raged in the city, business would remain stagnant, as rural farmers, purveyors of merchandise, and river traffickers refused to enter town. "The hotel registers begin to tell of the effect the small-pox scare in this city is having on the outside world," reported the Constitution. "The arrivals now are about one-third the usual number." Worries about potential loss of income caused the local press to begin noting instances of unfair quarantining against Keokuk. Finger-pointing put off one resident of nearby Alexandria, Missouri, who denied a newspaper report that Alexandria merchants were placarding against entry by Keokukians. "Our merchants themselves have been in your city purchasing goods since the small-pox broke out and people are here every day from your town. ${ }^{\prime 21}$

Word of the epidemic spread quickly, and damage control seemed to be the essential element in the townspeople's response. Within a week of the first smallpox deaths, the New York Times published a report of the "ravages of smallpox" afflicting Keokuk. Local health board president D. B. Hillis responded to queries by assuaging fears. "There is a limited number of cases confined entirely to medical students, and there is as yet no assured tendency to spread among citizens outside," reported Hillis. "Every means is being taken to lead [sic] off the epidemic and stamp it out, and with good hope of success." The local press on numerous occasions attempted to reeducate misinformed individuals who accepted unconfirmed stories as fact or who wrongly condemned the local board's efforts. "All kinds of wild and unfounded rumors still continue to exist," wrote the editor of the Constitution two weeks into the siege, "the generally accepted one outside of the city being that there are forty cases when there are only about ten." 22

Whatever response was to be made to the epidemic had to come from local sources; the State Board of Health offered no help. The state board instead spent most of the first three years of its existence setting up a rudimentary system of gathering information. It took two years alone to collect incomplete sta-

21. Keokuk Constitution, 5, 6 January 1882; Keokuk Weekly Gate-City, 6 January 1882.

22. New York Times, 6 January 1882; Keokuk Constitution, 7 January 1882; Keokuk Weekly Gate-City, 12 January 1882. 
tistics on births, deaths, and marriages from Iowa's ninety-nine counties for the single year of $1880 .^{23}$ Later, use of telegraphy greatly enhanced the board's ability to collect data speedily, especially after it instructed county clerks to charge all communications to the board. But Keokuk officials handling the smallpox epidemic of 1881-82 could not legitimize their efforts by appealing to a more objective outside body, nor did they wish to.

WITHIN FIVE YEARS, local authorities did begin using such a resource, as they drew expertise from a state board devoted to promoting public health. Remittent importations of smallpox into rural Worth County from 1886 to 1904 illustrate how local boards gradually yielded authority to the state board. The local response also suggests that citizens perceived in the outbreaks an outside threat to their way of life. Many times over the years, new immigrants and travelers imported smallpox epidemics into this rural community. At irregular intervals, dozens of people fell ill from the disease, and a few lost their lives. ${ }^{24}$

Two smallpox epidemics in particular are significant in describing disease fighting by both the local Worth County boards and the state board. In response to a new local code requiring that the state board be notified of all epidemic diseases and noxious hazards, both physician D. S. More of Northwood and the clerk of rural Barton Township in eastern Worth County reported in July 1886 "a number of persons exposed" to the contagion by a recently arrived German immigrant family. In December 1899 a separate epidemic began, which authorities traced to a street carnival in Albert Lea, Minnesota. One of the fair-goers, it was reported, was "allowed to go about at large in Northwood, with a small-pox rash broken out on his face and all over his body for nearly forty-eight hours." 25

23. Iowa State Board of Health, First Registration Report (Des Moines, 1883), vii-viii. State Board Secretary R. J. Farquharson pointed out in the preface of the report that the computed death rate for the state -6 per $1,000-$ was highly unlikely considering that the "settled" state of Massachusetts reported a rate three times as high.

24. Biennial Report 4 (1887), 43; Transactions of the Iowa State Medical Society 17 (1903-4), 215.

25. Biennial Report 4 (1887), 43; Worth County Index, 13 December 1899. 
Resistance from within the German-born population to measures taken by local officials justified the state board's decision to step in and attempt to reestablish order during the 1886 epidemic. In response to reports from local officials, the state board had wired the Barton Township clerk to "establish vigorous quarantine of all small-pox cases and exposed persons, and order and enforce general vaccination, to prevent spread of disease, and obey rules of State Board." The same day the Barton Township Board of Trustees wired back that all efforts to secure compliance with their orders had been thwarted by a popular challenge to their authority, and they did not know how to deal with the "ten or fifteen exposed persons [who] refuse to obey trustees." The Worth County Index recounted in its first story on the epidemic in Barton Township, "The local board quarantined the Dietrick and Brown families [where the smallpox had first erupted], but were powerless to enforce their orders, and the German minister of Grafton, as well as many of the neighbors visited the sick daily and insisted that it was not the small pox and there was nothing to fear." ${ }^{26}$

At that point the state board and the county sheriff were called in. The secretary of the state board reported that local officials manifested "an earnest desire . . . to do all that was necessary to get rid of the scourge, but they did not know what to do. They were further embarrassed by the interference of pretended physicians who pronounced the disease not smallpox, and advised resistance to all orders of the local board." Compounding the problems in maintaining quarantine regulations and encouraging vaccination, the doctor hired to vaccinate county residents skipped town and was not heard from for many weeks thereafter. This doctor later sent his apologies, claiming he had been hurriedly called away to investigate a mysterious disease afflicting his own hometown. Another doctor hired by the state board to treat smallpox cases in Barton Township was not allowed to return to his office in Northwood for fear that he "would not know enough to properly disinfect himself before leaving the infected houses. ${ }^{27}$ 
Under increasing pressure from the state board, local officials began arresting and prosecuting those who refused to obey the quarantine. Two members of the Dietrick family were fined twenty-five dollars each, while a similar case was remitted on the grounds that the defendant was "a Dane who recently arrived in this country and he was not sufficiently acquainted with the language to understand that the town trustees had provided means for furnishing all necessary supplies to the parties who were quarantined." Clearly, the Index reported, township officials had shown that they "don't propose being trifled with." ${ }^{28}$

In 1899 rumors of a renewed outbreak of disease abounded in Worth County. According to attending physician J. Herbert Darey, "cries of 'Cuban itch,' 'Philippine itch,' 'chickenpox,' 'ruin the holiday trade,' etc. were heard on all hands, till the mayor, at the insistence of a number of the leading citizens, did what I requested him to do on the start, viz:- request the State Board of Health to send an expert to Northwood, to see if it was really smallpox or not." State Board President J. C. Schrader arrived from Iowa City in short order and concluded that the cases in question were indeed smallpox, though of an attenuated form. "This was the first case of smallpox Drs. Hurd, Stixrud, and myself, had ever happened to see," Darey related later, "and we were much encouragd [sic], and eased in our minds, by Dr. Schrader's confirmation of our diagnosis." Resistance to vaccination efforts in Silver Lake Township, "owing to the statements of a physician in another town, who backed them up in their obstinancy [sic]," were also overcome when reports of the malady mailed to the board in Des Moines returned with a commandment to quarantine for fear of smallpox. ${ }^{29}$

This time the state board directed most of the actions of local health boards. While aiding in the writing of an extensive code concerning public health in Northwood, the state board directly implemented quarantine and preventative measures to stave off the virus. The board also encouraged county mayors and aldermen to exercise their right to create local boards of

28. Worth County Index, 29 July 1886 . The German family's name was spelled Dietrick in the July 22 edition and Dietrich in the July 29 edition.

29. Transactions of the Iowa State Medical Society 18 (1904), 215-16. 
health where there were none. Local boards were also instructed in the disinfection of homes and were legally empowered to remove a "sick or infected person to a separate house, if it can be done without damage to his health, and [to provide] nurses and other assistance and supplies, which shall be charged to the person himself, his parents or other person who may be liable for his support, if able; otherwise at the expense of the county to which he belongs." In turn, local authorities drew up a new Northwood ordinance, which filled two pages in the Index and included more than thirty sections concerning disease control, burials, and penalties for defiance. Finally, a state law passed in 1897 enabled the local Worth County boards to arrest those inoculating with smallpox-which unlike cowpox vaccination makes the individual a carrier of the disease-or knowingly using public transportation while infected. ${ }^{30}$

The Index itself served to defuse panic as the smallpox advanced, dispelling wild speculation and providing constructive information. "Now, don't be alarmed," announced one article. "There is doubtless a light case of smallpox in this town. The facts in the case we have gleaned from Dr. Darey, and those in which the public has a legitimate interest are herewith given as follows." Another issue assured readers, "You are in no danger of catching smallpox by long distance telephone." ${ }^{131}$

Darey also turned the economic argument against treatment on its head as he and others vaccinated 335 individuals in Danville Center in 1899-1900. "The best method of overcoming prejudiced and unreasonable objections to vaccination," wrote Darey, "was to state gladly that this virus is expensive and hard to get." He would continue with words to this effect,

"And now Mr. Wiseman, if you would rather not have it used on your family, Mr. Needit is very anxious to have it at once, as he can ill afford the quarantine and the sickness, while you are well to do and would not be seriously inconvenienced should the sickness come." In about three days 90 per cent of these will complain of unfair discrimination ... making good the adage,

30. Laws of Iowa (1880), chap. 151; Northwood Municipal Code, Ordinance No. 90 (1886); Code of Iowa (1897), chap. 10.

31. Worth County Index, 7, 14 December 1899. 
"When you learn which end of the pig the head is on you have no trouble in driving him. ${ }^{\prime 32}$

ALTHOUGH officials in Worth County relied heavily on the authority of the state board of health, the limits of the board's intervention were apparent even at the turn of the century. Those limits are demonstrated in a smallpox epidemic that affected a wide area of southwest Iowa and eastern Nebraska in 1898-99. The Fremont Democrat-published in Hamburg, Iowa-portrayed in its stories a county under siege by an invisible invader that threatened the economic life of the city. Blame for the debacle was placed squarely on its neighbor across the Missouri River, Nebraska City, where smallpox had gotten completely out of control. This epidemic revealed most strikingly the inability of the local Fremont County boards to control what had become an interstate problem. ${ }^{33}$

The State Board of Health did offer its encouragement and limited support as the epidemic threatened to engulf the state. By the late 1890s, the board was waging war against disease on a number of fronts. It was, for example, encouraging improvements in sanitary and water systems and the development of a new diphtheria vaccine. Epidemic outbreaks were reported by wire directly to the board offices in Des Moines, then transmitted to health officials and appointed district officials who could benefit from the knowledge. During the smallpox epidemic of 1898 , the city clerk of Hamburg and local county boards of health remained in constant contact with the state board, both to warn of the possible spread of the epidemic and to solicit opinion. The state board had offered indirect support to local communities since the mid-1880s, but asserted vehemently that its advice was "given for the benefit of local boards that they may more fully understand their duty in the premises, and the necessity for prompt and vigilant action." Thus, local boards

32. Transactions of the Iowa State Medical Society 18 (1904), 218.

33. Fremont Democrat, 18 November, 16 December 1898; Biennial Report 10 (1899), 100. The explosion in smallpox cases was blamed on Nebraska's State Board of Health, which had run out of funds. See Nebraska City Daily Press for 1898 and 1899. 
were charged with ultimate responsibility for ending smallpox incursions. Educated by the state board, they were to prepare carefully for epidemics and act judiciously when they struck. ${ }^{34}$

The Fremont County epidemic began in mid-November 1898, when Mrs. Samuel Townsend returned from a visit to a married daughter in Nebraska City who was sick with an "eruptive fever, but not well defined." Although Mrs. Townsend was only mildly affected herself, her family was quickly and seriously infected. On November 18 the city clerk telegraphed the state board to report the outbreak. He noted that the mayor had appointed four police to guard the Townsend residence - "two by night and two by day." The same afternoon, local physician W. L. Bogan wired the state board to ask what additional steps should be taken to stem the spread of the smallpox. "The local board of health has the case quarantined, and we hope to prevent the spread of the disease," wrote Bogan. "Any information from you will be gladly received and duly appreciated by your humble servant." ${ }^{13}$

The next day Hamburg's local press, the Fremont Democrat, began reporting the course of the epidemic as it spread outward from the Townsend family, and from a felled contract laborer home from Nebraska City. The Democrat praised the mayor and town physicians for their quick reaction to the disease and the subsequent quarantine. The paper noted with concern, however, that another of Mrs. Townsend's daughters had continued to attend public school, much to the consternation of the teachers and pupils. Further infection arrived by steady communication across the railroad trestle bridging the Missouri. "We have quarantined against Nebraska City, Neb., but we are unable to place a quarantine at the bridge," lamented the city clerk in a communication to the state board, "and we are in great danger by people coming here from Nebraska City." He added, "Our cases are all well. We don't want any more. . . . Please attend to this immediately." ${ }^{\prime 36}$

34. Biennial Report 4 (1887), 43.

35. Biennial Report 10 (1899), 100-101.

36. Fremont Democrat, 18 November 1898; Biennial Report 10 (1899), 101. 
As alarm spread, other Fremont County communities began to request the state board to step in and establish a more secure quarantine against Nebraska City. J. A. Armstrong, Percival's mayor and de facto local health board president, sent a telegram to the state board, pleading, "A new disease has broken out in our midst that is causing us lots of alarm, and the doctors do not agree as to its character. Some call it smallpox and some do not. .. W Will you please advise me what to do?" Two weeks later, on Christmas Eve, Armstrong requested that the state board draft men to guard the bridge spanning the Missouri. "A great many people are daily passing from Iowa into $\mathrm{Ne}-$ braska City for the purpose of trading," wrote the mayor. "Consequently, we are very anxious to have guards stationed there." Armstrong apologized that town officials were unable to stop the trade, explaining that strict quarantine "would have been done before now if our local board had understood the necessary steps in the proceeding. ... We shall be very glad to have you take active measures at once. ${ }^{137}$

Pleas received from officials in Hamburg, Percival, and rural Fremont County townships prompted the state board to send district physician Dr. McKlveen to report on the situation firsthand and explain to county boards the principles of restricting smallpox. McKlveen wrote to the chairman of the local board at Percival, "asking if it would still, in their opinion, be necessary for me to go up to their place, and they replied they thought it would." After meeting with the local board and doctors, he concluded that "the board at Percival seems to understand that they have the full power of quarantine, but claim to lack the means for doing it." The task was more formidable than either the state board or McKlveen had anticipated. Not only would they have to quarantine the railroad and wagon bridge that connected Nebraska City with Iowa, but also miles of the river bank as well, "as the river is frozen over and persons can cross on the ice. ${ }^{\prime \prime 38}$

There were financial complications as well. "The [Percival] board claimed to be willing to look after the quarantine," wrote

37. Biennial Report 10 (1899), 101-2.

38. Ibid., 103-4. 
McKlveen, "but thought inasmuch as it was an interstate quarantine, the State should pay the expense," which they estimated at about eight dollars per day. The state board was reluctant to do so, however. Never before had the board earmarked money directly for such activities. McKlveen doubted that the state even had any funds for such purposes, but promised to write to the governor about it. Percival's physician, M. L. Thomas, thought that the state's failure to offer financial support could have disastrous consequences. Although "local authorities here are doing all in their power to stamp out this disease," he worried that "they are becoming discouraged in their work. . . . I fear if the State does not help in this matter this part of Iowa and other parts of the State will have the greatest epidemic of smallpox it has ever had, and will cost the State and counties a great amount of money." ${ }^{\prime 39}$

One of McKlveen's most important duties during his stay in Fremont County was to disseminate information concerning the prevention of smallpox. As the disease continued into the spring, instruction provided by McKlveen encouraged such measures as vaccination and disinfection. McKlveen suggested that all structures containing smallpox patients be thoroughly fumigated, and the board issued a pamphlet recommending the best means of fumigation. Their advice was followed throughout the county. When two fresh cases of smallpox appeared in Hamburg in May 1899, for example, a local doctor wrote that "all doubtful clothing, bedding and draperies were burned. . . . I had the stable and the horses disinfected, also the privy vault, by using a solution of sulphate of iron and carbolic acid. I had the yard raked and rubbish burned, then had the yard and walks sprayed with solution of sulphate of iron." Moreover, Bogan "had the parties all bathed, then washed in a solution of carbolic acid and dressed in clean clothing. I had each room fumigated with sulphur, cooled them off, and then used formaldehyde for six hours, opened the appartments [sic] and thoroughly ventilated them, and moved the family in; considering there was no more danger." Although it is doubtful that any of these techniques worked, they do illustrate the 
degree to which local boards responded to the state board's authority. ${ }^{40}$

The Democrat appeared to view the disease with more equanimity than had the Keokuk papers nearly twenty years earlier, but it did decry the state of affairs in Nebraska City that had caused the calamitous epidemic. "Now when the Democrat stated some two weeks ago that there were cases of small-pox in Nebraska City, the papers of that town stated emphatically that the disease was not small-pox but merely chicken-pox," the paper reported. "They also published a statement in the Press with the names of prominent physicians of that town signed to it stating that there were no cases of small-pox in Nebraska City. The fact is that the business men of Nebraska City concluded that it would cause a stagnation of business in the town if they allowed the report to be circulated that there were cases of this dread disease in their city." ${ }^{\prime 1}$

Fremont County residents were just as concerned as Nebraska City merchants about protecting local trade. While condemning Nebraska City's "smallpox situation" as "absolutely wretched," the disease was being perpetuated on the Iowa side by business people intent on maintaining trade with the offending riverport. The publisher of Hamburg's weekly religious newspaper, and "one of our most law abiding ? citizens," found the quarantine of little consequence. The Democrat strongly objected to his recommendation to a young schoolteacher that "she could slip over to Nebraska City like he used to do when Hamburg was quarantined last month, and that ... it would be alright." Still, the paper itself was plainly complicit in understating the epidemic's seriousness, for although the Hamburg clerk of court reported twenty-seven cases to the state board for fiscal year 1898-99, the newspaper mentioned only four cases directly. Wright's Department Store, which bought advertising on the front page of every issue of the weekly Democrat, insisted unabashedly in their space in mid-February that "there is not a case of smallpox in Hamburg and has not been for 4 weeks, and that there is no

40. Iowa State Board of Health, Restriction and Prevention of Small Pox (Des Moines, 1881), 5-7; Fairchild, "Brief History," 480.

41. Fremont Democrat, 18 November 1898. 
quarantine against any of our neighbors." Although the comment about the quarantine was true, the claim about smallpox was patently false. Persons exposed to smallpox in Nebraska City were in Hamburg nearly every day, and many cases undoubtedly went unreported for fear of inviting quarantine at home or in a drafty building outside the city limits. Town leaders quarantined against Nebraska City reluctantly, hoping that this time the health board's edict would be obeyed. If not, "Hamburg would soon have the seeds of the disease once more sown in our city with the probable result of a serious seige [sic] of sickness, business stagnation and an enormous expense incurred to the city and county." 42

Nebraska City citizens, in their turn, believed that the epidemic had started among the more than 2.5 million people who attended the Trans-Missouri Exposition held between June 1 and October 31, 1898, in Omaha. Omaha's growing economic power and its potential for incubating disease weighed heavily on the minds of Nebraska City merchants who had watched their sales dry up in the fall. When the fair's promoters proposed to resurrect the enterprise for 1899, seventy-seven Nebraska City business owners lodged their protest by forming the Nebraska Business Men's Protective Association and issuing a circular letter to be published in newspapers across the state. The fair's chief promoters, they complained, "seem to be aware of the fact that there are still a few stray coins scattered over our state, and what better plan could be adopted than to start an exposition at public expense, gather in the stray coins and give nothing in return." Amid talk of a possible boycott, word of smallpox in Nebraska City prompted speculation that the Exposition was directly to blame. Regardless of how the rumor started, it was a useful claim when advanced by the Protective Association. The dual threat of potential economic ruin and smallpox proved an effective argument for the association. Another Exposition was never held. ${ }^{43}$

42. Ibid., 3, 24 February 1899.

43. Kenneth Gerald Alfers, "The Trans-Ms. Exposition" (M.A. thesis, Creighton University, 1968), 124, 133; Nebraska City News, 29 November, 13, 16 December 1898. 
THE HAMBURG-NEBRASKA CITY EPIDEMIC of 1898-99 probably arrived via a Missouri River steamboat. There was, however, an even more disquieting way for smallpox to enter the state. Iowa's Board of Health recognized that passenger rail travel, and especially the immigrants aboard the trains, carried the potential to spread disease. The board documented cases of immigrants, travelers, or hobos infecting Iowa communities (see table 2). Many articles in the public health journals and newspapers of the period lamented the double-edged sword of railroads and disease. The secretary of Iowa's board worried about the lack of control over this moving menace. "A great deal is being said about the commercial value of railroads," he noted, "and yet they have a sanitary value hardly less important." As local Iowa communities drew life-blood from railroads that had given birth to them, so also did they suffer from the railroads' occasionally deadly cargo. Rural towns were much less likely to refuse trains than for railroad companies to refuse service to towns suffering localized epidemics. The state board made numerous attempts to reduce the risk, but most were imperfect, ill conceived, or simply not in the best interests of the railroads. Still, encouraged by state and national boards of health, the railroads made efforts to vaccinate employees, disinfect passenger cars, and selectively forbid passage to those with obvious cases of disease. ${ }^{44}$

During the last two decades of the nineteenth century nearly all of Iowa's trunk rail lines originated in Chicago, where even after the city established a full-time municipal board of health in 1867, smallpox continued to trouble the city. Serious epidemics occurred in 1872 and 1882, and deaths from smallpox were recorded in all but five years from 1867 to 1900. Chicago's celebrated 1893 Columbian Exhibition became a magnet for infected visitors, necessitating the construction of a new smallpox hospital. In the three years after the opening of the fair, 3,754 cases of the disease were reported to Dr. Garrett, Chicago's chief medical inspector. Defending the healthfulness of the city, Garrett reported to the local board of health, "We

44. Bulletin of the Iowa State Board of Health 3 (1889), 6-8; Anderson, "'Headlights upon Sanitary Medicine,'" 192, 195; Biennial Report 1 (1881), 9-13, 16. 


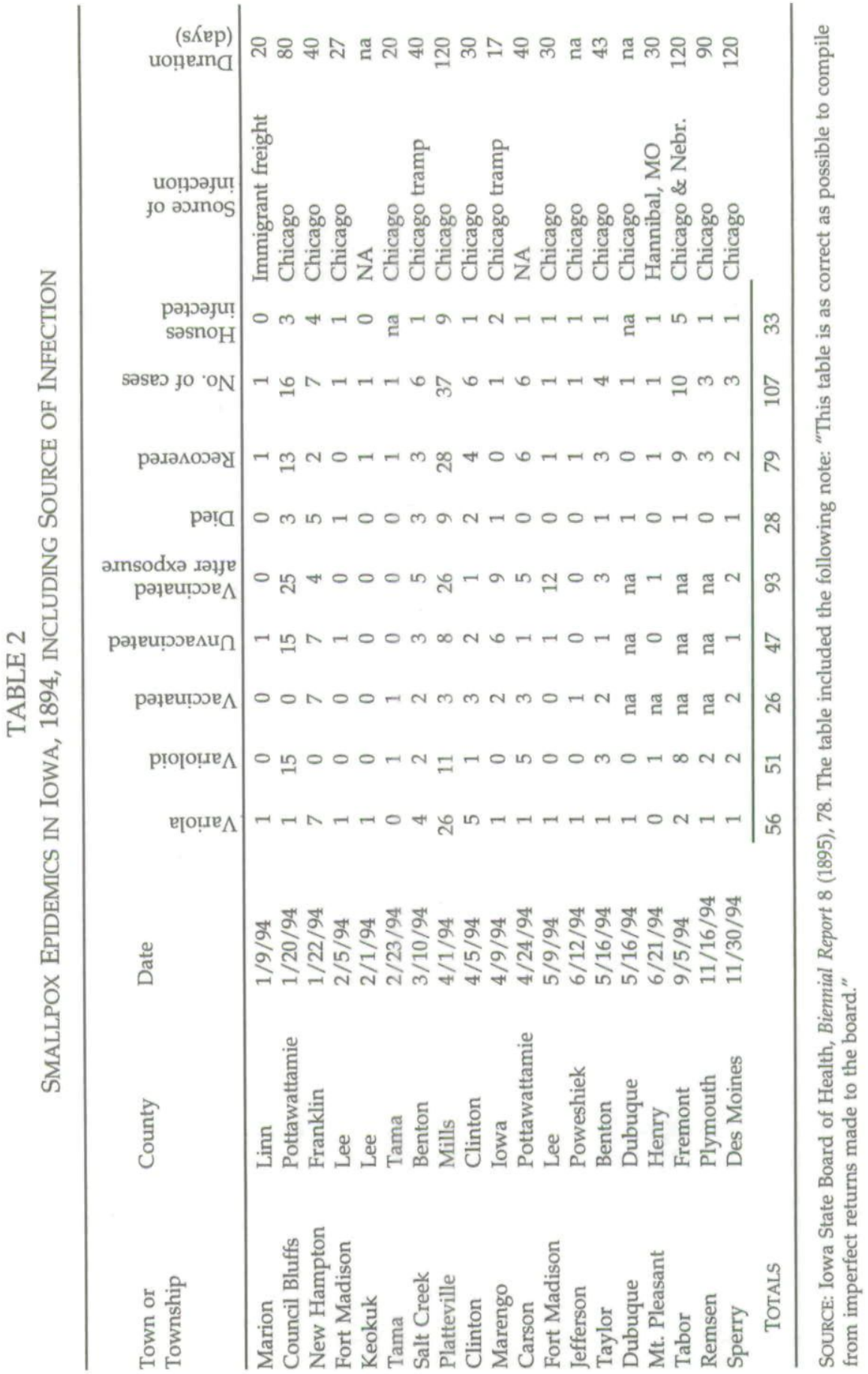


were able in every instance to trace the source of the contagion to other countries." ${ }^{45}$

More than a decade earlier, the increasing number of smallpox cases in Chicago had prompted a special meeting of the Chicago Board of Health and other midwestern health boards. Conferees at this Chicago Smallpox Conference in 1881 included Iowa State Board Secretary R. J. Farquharson; officials from the new but ill-fated National Board of Health; state board representatives from Wisconsin, Minnesota, Indiana, and Michigan; and local board members from Chicago, Milwaukee, Buffalo, and Baltimore. Participants at the conference urged health organizations to take care in quarantining and vaccinating their populations. "In view of the fact of the frequent introduction of small-pox into the interior of Iowa from immigrants," said Secretary Farquharson, "the Iowa State Board of Health would respectfully request the National Board of Health to secure the vaccination of all unprotected immigrants before they leave the ports of arrival in this country." Some conferees denounced the feeble efforts made by eastern ports to prevent diseases from propagating. Others complained that midwestern termini were becoming dumping grounds for sick immigrants. ${ }^{46}$

The Chicago Smallpox Conference and the pleas of midwestern public health authorities drew a response from the recently created National Board of Health, which created a special Immigration Inspection Service in June 1882 to check railroads, ocean steamers, and river transport for disease. Doctors were hired across the nation to inspect and vaccinate immigrants and travelers. From the start, though, the Immigration Inspection Service was ineffective in stemming the flow of disease across the Atlantic and from east to west. Inadequate numbers of inspectors were overwhelmed by the task; Chicago had only five physicians at its disposal, St. Louis

45. Rawlings, Rise and Fall of Disease in Illinois, 313-16. The only years between the founding of the Chicago Board of Health in 1867 and the turn of the century in which there were no reported deaths from smallpox were 1888, $1890,1891,1896$, and 1898. Mortality averaged 167 per year from 1867 to 1900 , with a high of 1,292 in 1882 and a total for the period of 5,535.

46. Rawlings, Rise and Fall of Disease in Illinois, 105, 145-48; Biennial Report 1 (1881), 167-69; ibid. 3 (1885), 46. 
and Indianapolis only two. An inspector proposed for Omaha was never funded. ${ }^{47}$

The Immigration Inspection Service had little immediate impact, but its existence had important ramifications. It contributed to the sense that "every organized community should be provided with a competent board of health, and the State with a State Board, supplied with every requisite for aiding and directing the local authorities in their sanitary work." More importantly, though, for a short time the Immigration Inspection Service was a visible reminder that disease was more than a local phenomenon, one that demanded coordinated efforts, and it provided a national forum for discussing ways to combat the health problems related to integrated, global transportation systems. In 1883, as the service was being phased out due to budget cuts and political infighting, sixteen local and state boards, including Iowa's, submitted a blanket recommendation to the National Board pleading for its continuation. The signers agreed that the service was necessary "to prevent the frequent introduction of small-pox and other contagious disease among the people of this country." Admitting their own inadequacy in meeting the epidemic threat, these boards noted that "this inspection service is such that its benefits have no relation to State boundaries, but its protective influences extend widely throughout this country; consequently, expenses therefore should not properly be borne by any local or State board of health." 48

47. Ralph C. Williams, The United States Public Health Service, 1798-1950 (Washington, DC, 1951), 76-79; Report of the National Board of Health (1883), 125-46. The National Board of Health lasted only six years (1879-1885). Overwhelmed by the scope of the problems it was to handle and besieged by political turmoil, its financial support was revoked by a Congress that expressed dissatisfaction with the board's lack of success in creating a more healthful American environment. The board was already operating on a shoestring budget when a costly yellow fever epidemic in Pensacola, Florida, in 1882 sealed its financial doom. The best history of the National Board of Health is Peter W. Bruton, "The National Board of Health" (Ph.D. diss, University of Maryland, 1974).

48. Rawlings, Rise and Fall of Disease in Illinois, 145-46; Biennial Report 3 (1885), 46; ibid. 1 (1881), 169; Annual Report of the National Board of Health (1883), 19. 
Although state veterinary surgeons had drawn up lengthy regulations to certify the health of cattle coming from areas where disease was plentiful, few similar laws were on the books for humans until the 1890s. The Immigration Inspection Service and the Iowa State Board of Health spurred Iowa rail companies to detain passengers who had obvious symptoms of smallpox, were incapacitated by dysentery, or were suffering from undiagnosed fevers. Iowa railroad stationmasters responded by disinfecting passenger cars just prior to their use. General Manager Marvin Hughitt of the Chicago \& North Western Railway Company ordered his employees and officers to inspect "passenger coaches, and especially those used for the transportation of seaboard emigrants" and make sure they were "thoroughly cleaned throughout" after every run. ${ }^{49}$ In 1894 management for the Chicago, Milwaukee, \& St. Paul Railway issued a circular making it the "duty of conductors to report by wire to their superintendents and the secretary of the State Board of Health any person on their train suspected of having small pox or cholera." Station agents were to report to the local board of health the arrival of all immigrants so that the board could inspect the immigrants and their baggage. Still, economic concerns prevented the national and state boards from demanding reform from railroad companies. National board physician Stephen Smith announced, for example, that "trains need not be delayed for the inspection may go on while the train is moving."

The Chicago \& North Western Railway epidemic of June 1889 provides an example of the rail-borne vector for smallpox in Iowa. The epidemic spread virtually from one end of the state to the other, although only two exposed individuals died. Imported among German immigrants aboard a crowded passen-

49. Biennial Report 4 (1887), 66-67; ibid. 3 (1885), 47-48. In 1897 stockmen organized the Interstate United States Livestock Sanitary Association, which dealt specifically with the infectious diseases and nutrition of animals. The association's Proceedings reveal that conferees were nearly as well informed as public health officials. See, for example, the floor debate on horse glanders at the 1904 annual meeting in Denver, Colorado, in Proceedings of the Seventh Annual Meeting of the Interstate Association of Live Stock Sanitary Boards 7 (1904), 66-67.

50. Biennial Report 8 (1895), 17; ibid. 2 (1883), 24. 
ger train, smallpox pustules were apparent on the face of one immigrant as the train entered the state. Nevertheless, no action was taken until stations along the route began complaining by telegraph to the state board. Clinton, Marshalltown, Nevada, Boone, and Jefferson each charged that smallpox had made its appearance in their communities coincidentally with the arrival of the train, leaving sickness in its tracks. Apparently, none of the station managers bothered to wire ahead and spare the next town. When the state board requested that exposed passengers be taken into protective custody, the mayor of Wall Lake in Sac County refused, saying that the board had to remove them from the community. The train was then sent on its way. At Galva, obstructions placed on the tracks forced the train to stop. The train was then moved onto a siding, and state board physician J. D. Miller quarantined the passengers and crew. The caboose in which the infected passenger had been riding was dragged to an Ida County gravel pit, where it was disinfected and abandoned. Regarding such problems as this, Secretary Farquharson was prompted to write, "Something more is required than the inspection and vaccination of passengers." Farquharson advocated the total isolation of immigrants on their journeys, sealed in their own cars as they crossed the state. That way, hapless Iowans need not suffer because "immigrants are mixed up with the passengers. ${ }^{151}$

True controls for diseases required immigrant inspection at the national border, which suggested federal authority. "If a proper examination of European immigrants was made at the point of embarkation, and the unvaccinated ones properly vaccinated," noted Secretary Farquharson, "there would be but little need of any inspection afterward on the railroads." National Board of Health physician Stephen Smith responded, "Your suggestion is the one that the National Board has been acting upon, but in every attempt it has failed owing to defects in the law. It cannot enforce vaccination, either at foreign ports or home ports under existing laws." ${ }^{52}$

51. Biennial Report 5 (1889), 19; Monthly Bulletin of the Iowa State Board of Health 3 (1889), 6, 14-15; Biennial Report 2 (1883), 84.

52. Biennial Report 2 (1883), 25, 84. 
Finally, in 1891 Congress ruled that immigrants were to be screened both for pestilential diseases and epilepsy as well as for their moral character. That legislation did not remove the immigrant vector for disease, but it did lessen it substantially. The widening scope of activity by the United States Public Health Service also limited the extraterritorial introduction of disease into Iowa and the nation. Facilities for quarantine of vessels were constructed at significant points of entry each year until detention stations were in operation at every major seaport and border crossing in the nation. ${ }^{53}$

CONCERN ABOUT SMALLPOX slowly weakened as the turn of the century approached, not because of the activities of health organizations, but because $V$. minor replaced $V$. major as the main type of infection. Mild cases of the disease were already present in Iowa by the 1880s, and were often confused with chickenpox. Still, they could elicit panic. "All cases of chicken-pox during the prevalence of small-pox in any part of the coun-try should be regarded with the greatest possible doubt and suspicion," warned Secretary Farquharson. "An error of diagnosis is frequently followed by grave consequences." Des Moines adopted a siege mentality when two young boys and three girls in two families were incorrectly identified as exhibiting small-pox in 1892. Although the children began recovering within the week, the physician employed by the board of health to attend the children "stoutly maintained that the disease was small pox and urged the board not to release the quarantine." Three more weeks passed before the quarantine was lifted. "It seems incredible," state board physician E. H. Carter wrote later, "that in the city of Des Moines, two families should have been taken from their homes, placed in a pest house, guarded by officers and kept there for nearly a month during the development of six or eight well marked cases of chicken pox. ${ }^{154}$

53. U.S. Public Health Service, Environment and Health (Washington, DC, 1951), 79-80; Ralph Chester Williams, The United States Public Health Service, 17981950 (Richmond, VA, 1951, 84-88, 835.

54. Biennial Report 7 (1893), 7-9. 
Increased incidence of the weaker strain of smallpox modified attitudes toward the disease soon after the turn of the century. One unusual, though worthless, response was the popularization of "red light" treatments for smallpox sufferers. The treatment, called "erythrotherapy" by its developer, Dubuque physician J. C. Hancock, employed natural light diffused with a red screen purportedly to reduce the unpleasant scarring of the face and body that accompanied an attack. Concern about scarring had been of little consequence in previous centuries, when mortality had been very high. ${ }^{55}$

By the turn of the century, the changing nature of smallpox had a similar effect on the state board's approach to the disease. Instead of stressing its mortal effect, the board issued posters and other pamphlet material designed to portray those who refused vaccination as uneducated, and those who suffered the disease as threats to society. ${ }^{56}$

In the preceding decades the Iowa State Board of Health had added a new voice to the debate over the relationship between epidemic disease, immigrants, and the marketplace. However, the board could do little to prevent the further spread of smallpox but share its expertise and lend its authority to encouraging the use of the cowpox vaccine and the quarantine of exposed persons. Only the proliferation of a mild strain of the virus, not the recognized efforts of the Iowa State Board of Health, worked to stem the public panic long associated with smallpox.

55. Donald R. Hopkins, Princes and Peasants: Smallpox in History (Chicago, 1983), 298-99.

56. Anderson, "'Headlights upon Sanitary Medicine,'" 195; Iowa Health Bulletin 23 (1910), 54-69. 
Copyright of Annals of Iowa is the property of State of Iowa, by \& through the State Historical Society of Iowa and its content may not be copied or emailed to multiple sites or posted to a listserv without the copyright holder's express written permission. However, users may print, download, or email articles for individual use. 